Miroslav M. Jovanović

Technical Test Cente Serbian Armed Forces Belgrade

Aleksandar M. Simonović

Associate Professor University of Belgrade Faculty of Mechanical Engineering

Nemanja D. Zorić

Assistant Professor University of Belgrade Faculty of Mechanical Engineering

Nebojša S. Lukić

Technical Test Cente Serbian Armed Forces Belgrade

Slobodan N. Stupar

Full Professor University of Belgrade Faculty of Mechanical Engineering

Ana S.Petrović

Teaching Assistant University of Belgrade

Faculty of Mechanical Engineering

Wei Li

Associate Professor Xidian University, Xi'an

\section{Experimental Investigation of Spillover Effect in System of Active Vibration Control}

Piezoelectric actuators are widely used in structural systems for active vibration control with the aim to enhance the performance of systems. The developed system of active vibration control consists of active structure, controller and high voltage amplifier. In this paper, the composite beam is host structure for sensor platform (strain gages) and actuator platform (dual layer PZT piezoelectric actuator). In order to improve the dynamic characteristics of active system, the coefficients of PID controller are changed. The effectiveness of active vibration control system at mode of interest can be improved with change of PID coefficients, but the stability of system can be reduced. The instability of the active structure is often perturbed by spillover effect. In this paper the importance of considering spillover effects in closed loop of piezoelectric active structures is demonstrated and shown the importance of change the PID coefficients in stability of active vibration control system. Experimental results which correspond to the developed active vibration control system are presented and affirmed stability on proposed active structure.

Keywords: Active vibration control, piezoelectric actuators, strain gages sensor, PID controller, spillover effect.

\section{INTRODUCTION}

Composite structures are widely applied in the aerospace and arms industry as well as in robotics, sports equipment and medical prosthetics. The active vibration control of these structures is of great importance in enhancing safety and improving system performance, because the occurrence of unwanted vibrations may result in instability, decreased performance, and can also lead to catastrophic failure [1]. In order to suppress vibrations during use, conventional structures have been combined with sensors and actuators to form so-called smart structures.

The structure with sensor-actuator pair which is coordinated by a controller called smart structure. The performance and functionality of smart structures depend on control algorithm. The piezoelectric materials, such as lead zirconate titanate (PZT), are usually used for actuators. The materials have the property to generate electrical charge under mechanical load or deformation and the reverse; applying an electrical field to the material results in mechanical strains or stresses [2].

Depending on the integrated sensor, the vibration can be controlled by different control algorithms. The most commonly used control algorithms are classical

Received: May 2014, Accepted: November 2014

Correspondence to: PhD Nemanja Zorić

Faculty of Mechanical Engineering,

Kraljice Marije 16, 11120 Belgrade 35, Serbia

E-mail: nzoric@mas.bg.ac.rs

doi:10.5937/fmet1404329J

(C) Faculty of Mechanical Engineering, Belgrade. All rights reserved control algorithms such as direct proportional feedback/ constant gain velocity feedback (CGVF)/ constant amplitude velocity feedback (CAVF), PID control algorithm [3-7].

Fundamental qualitative properties of dynamic systems are controllability and observability. Generally speaking, controllability corresponds to the ability of steering the state vector from one vector value to any other vector value in finite time. A system is said to be controllable if every state vector can be transformed to a desired state in finite time by the application of unconstrained control inputs. Observability analyzes the deductibility of the initial state vector of the system from knowledge of the input and the corresponding output over time [8].

Flexible smart structures are distributed parameter systems that have an infinite number of degrees of freedom. Active vibration controller design often requires a mathematical model of the structure, which is at best a reduced-order model with only a finite number of coordinates. A feedback controller based on a reduced model can destabilize the residual modes (unmodeled dynamics). In function of sensor position the feedback can excite the unmodeled state of system (control spillover), and the sensor signals are contaminated by the residual modes (observation spillover) and degraded the active vibration system efficiency. In $[9,10]$, the methods to reduce the effects of spillover are investigated.

This paper presents an experimental investigation of spillover effect on smart beam active vibration control system affected by different coefficient gains of PID 
control algorithm. The research of instability of the active vibration control was performed on composite beam using full bridge strain gages for sensor platform and bonding piezoelectric patches for actuator platform. The PID control algorithm is implemented on a 'PIC32PINGUINO-OTG' board [6, 11], with an integrated PIC32MX440F256H microcontroller. The experiment considers vibration control under periodic excitation at the eccentricity pulley.

\section{EXPERIMENTAL SETUP}

The active structure comprises a cantilever composite beam, $310 \mathrm{~mm}$ long, $60 \mathrm{~mm}$ wide and $1.5 \mathrm{~mm}$ thick, piezoelectric patch (MIDE QP20w), $50.8 \mathrm{~mm}$ long, 38.1 $\mathrm{mm}$ wide and $0.76 \mathrm{~mm}$ thick, which is bonded on upper side and $25 \mathrm{~mm}$ away from the clamped edge and set of $120 \Omega$ Wheatstone bridge which are bonded at $25 \mathrm{~mm}$ from the clamped edge. At the free end the mount with pulley is integrated, which is connected across rubber belt with eccentric pulley driven with electric motor. The active structure is presented in figure 1.

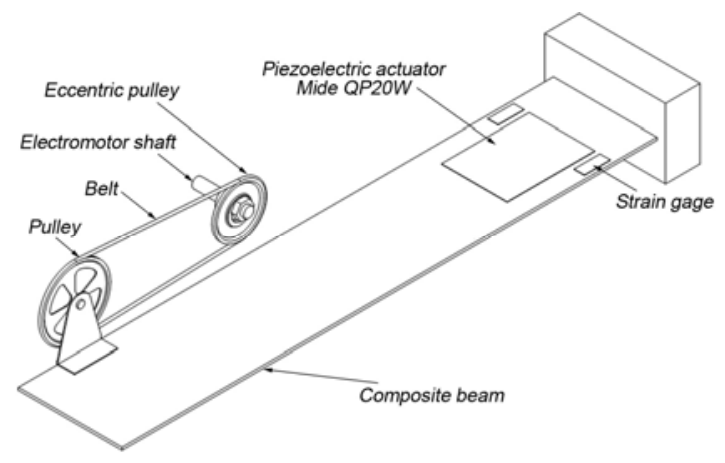

Figure 1. Cantilever composite beam with integrated piezoelectric actuator and strain gage sensors

The figure 2 presents a schematic diagram of the experimental setup considered in this study.

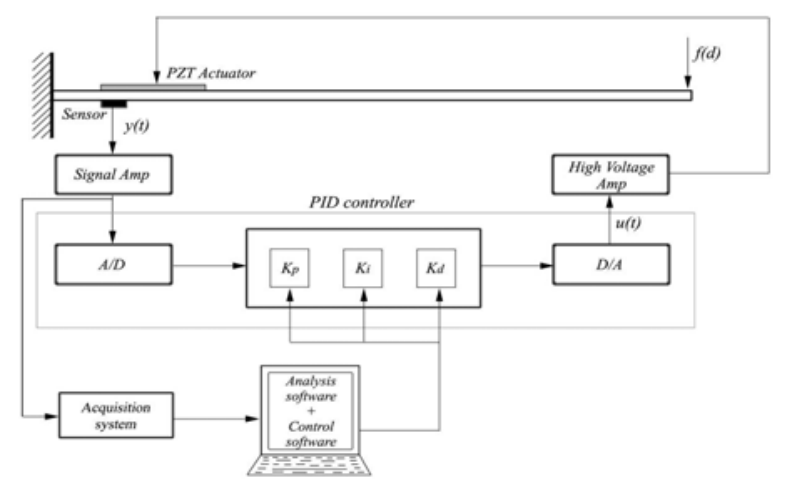

Figure 2. Schematic diagram of the experimental setup

To measure the displacements, strain gage sensors (Wheatstone full bridge) are considered. A signal amplifier is used to amplify the signal from the strain gage sensors. The analog signal from the signal amplifier is converted to a digital signal by the 16 bit $\mathrm{A} / \mathrm{D}$ converter. The control PID algorithm is implemented on a 'PIC32-PINGUINO-OTG' board with an integrated PIC32MX440F256H microcontroller. The digital signal from the microcontroller is converted to an analog signal by the 16 bit $\mathrm{D} / \mathrm{A}$ converter, and then passed through a second-order low-pass reconstruction filter with the aim of preventing aliasing in the conversion of samples back to a continuous signal. The analog signal is amplified by the voltage amplifier and fed to the piezoelectric actuator. The voltage amplifier and the board which carries the A/D and $\mathrm{D} / \mathrm{A}$ converters were developed for the purpose of experimental investigations of active vibration control. In order to achieve periodic excitation, an eccentric pulley is mounted at the tip of the beam (figure 1). Periodic excitation is achieved by the electromotor and is transmitted to the eccentric pulley using a belt $[6,11]$.

A system of active vibration control with active structure, PID controller, high-voltage amplifier and other measurement equipment is presented in figure 3 .

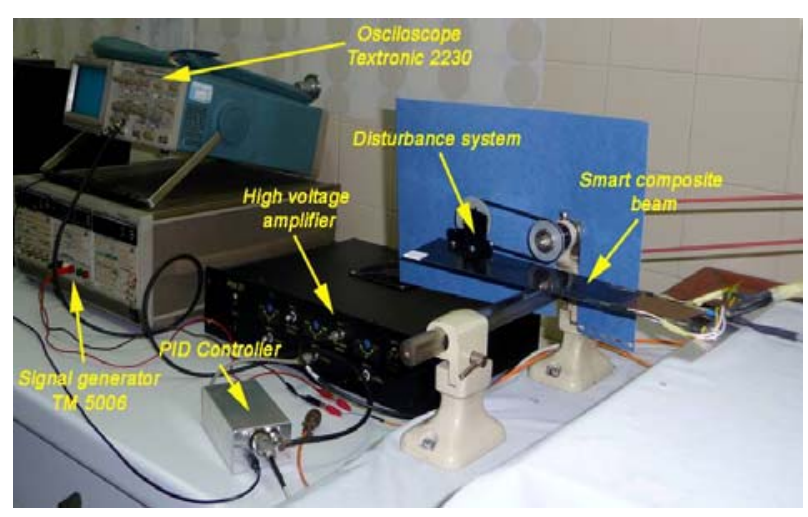

Figure 3. System of active vibration control

\section{IDENTIFICATION OF DYNAMIC PARAMETERS}

A process of the system dynamic parameters identification is important for the adequate adjustment of the control system [12, 13]. In our case we considered the natural frequencies identification for the first two modes. For this purpose the next two steps are considered:

- The measurement of the input/output data of the laboratory model, and

- The determination of the Frequency Response Function (FRF) from the input/output data.

The recorded voltage of output signal of the structure vibration in the $\mathrm{Y}-\mathrm{Z}$ plane is shown in figure 4. The free vibrations of active composite beam in open loop are cancelled after 6 seconds.

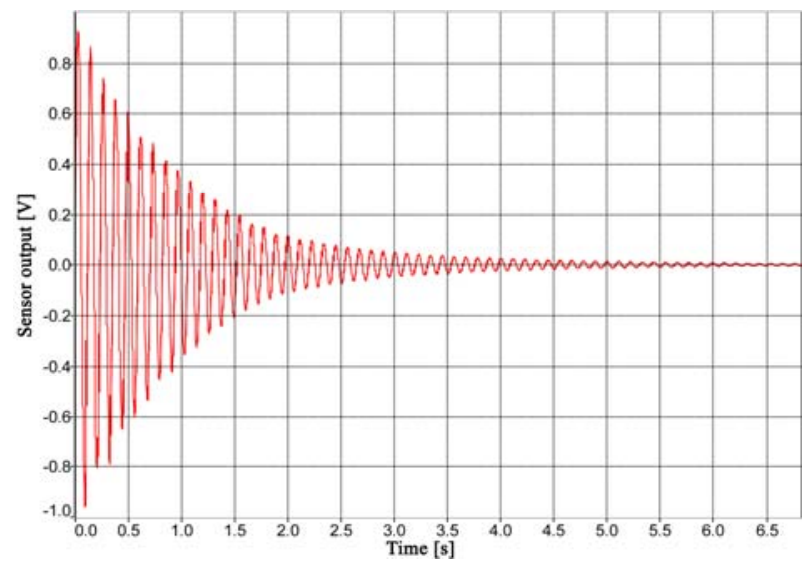

Figure 4. Output signal from "full bridge" strain gages measured by acquisition system 
On the basis of the output signal and their Fast Fourier transforms (FFT) the frequency response function was determined. As a result the plot of the amplitude versus frequency in the range from $1 \mathrm{~Hz}$ to $100 \mathrm{~Hz}$ was obtained. In figure 5 we can notice that the first two natural frequencies of system are $9.2 \mathrm{~Hz}$ and $30.1 \mathrm{~Hz}$.

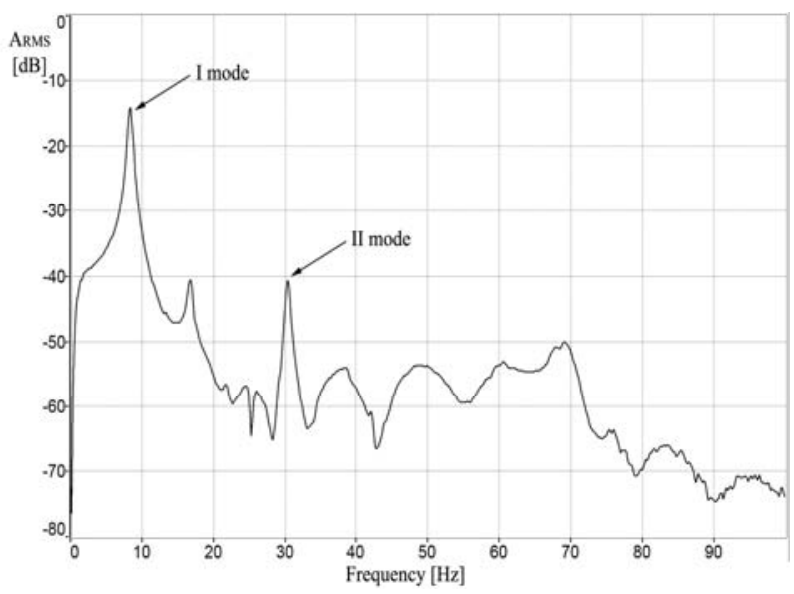

Figure 5. Amplitude-frequency characteristics

\section{EXPERIMENTAL RESULTS OF ACTIVE VIBRATION CONTROL SYSTEM}

In this section, the results of composite beam vibration active damping system via PID feedback controller are presented. The experimental results are given in time and frequency domains.

This section considers the case of periodic excitation on first bending resonant frequency of the plate, which is $9.2 \mathrm{~Hz}$.

Proportional, integral and derivative gains of the proposed PID are obtained by using the Ziegler-Nichols method. In Ziegler-Nichols method, the important step is the determination of critical gain (gain margin of the closed-loop system). The critical gain, $K_{c r}$ and period, $P_{c r}$ are defined as the amplifier ratio at which response of the controlled plant has sustained oscillations and closed-loop system is at the stability limit. The coefficient gains of $K_{p}=2.4, K_{i}=0.03, K_{d}=30$ are determined by the Ziegler-Nichols method. The transition period of sensor output voltage is depicted in figure 6 .

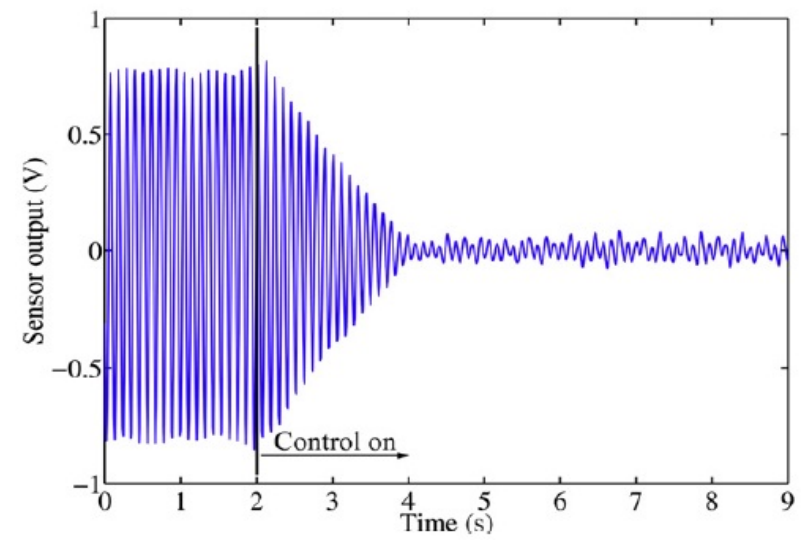

Figure 6. The transition period of sensor output under periodic excitation
In order to investigate how different values of proportional, integral and derivative factors affect control performances, an experiment was performed for several combinations of these factors. The proportional coefficient is changed. The first set of experiments is presented in Table 1, where the normalized root-meansquare (rms) sensor output voltage for uncontrolled case and each combination of factors as well a decrease in magnitude obtained by active vibration control are presented. In figure 7, the case of the best active vibration control with coefficient gains of $K_{p}=2.6$, $K_{i}=0.035, K_{d}=35$ and decreased in magnitude by $93.94 \%$ are shown.

Table 1. Normalized rms sensor output voltage for different factors and decrease in magnitude

\begin{tabular}{|c|c|c|c|c|}
\hline $\mathrm{K}_{\mathrm{p}}$ & $\mathrm{K}_{\mathrm{i}}$ & $\mathrm{K}_{\mathrm{d}}$ & $\begin{array}{c}\text { Magnitude at first } \\
\text { resonant mode, } \\
\mathrm{A}_{\mathrm{RMS}} \\
{[\mathrm{mV}]}\end{array}$ & $\begin{array}{c}\text { Damping at } \\
\text { first resonant } \\
\text { mode [\%] }\end{array}$ \\
\hline \multicolumn{3}{|c|}{ Uncontrolled } & 485.70 & $/$ \\
\hline 2.4 & 0.030 & 30 & 35.72 & 92.64 \\
\hline 2.6 & 0.030 & 35 & 34.85 & 92.82 \\
\hline 2.4 & 0.035 & 30 & 33.87 & 93.02 \\
\hline 2.6 & 0.035 & 35 & 29.42 & 93.94 \\
\hline 3.0 & 0.035 & 40 & 30.05 & 93.81 \\
\hline 3.0 & 0.040 & 45 & 23.85 & 95.08 \\
\hline 3.5 & 0.040 & 50 & 23.90 & 95.08 \\
\hline
\end{tabular}

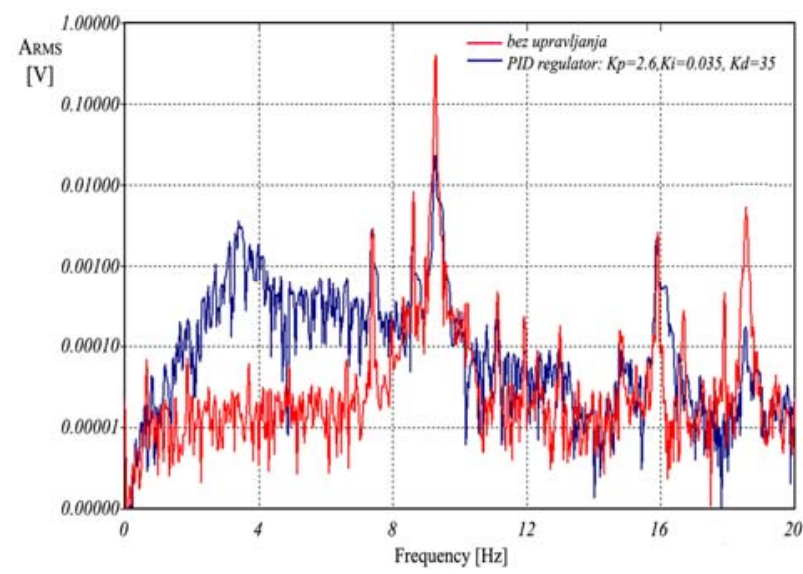

Figure 7. The frequency response using FFT for the uncontrolled and best controlled cases

It can be seen from Table 1 that control performances of the PID controller are changed with a variation of three factors. The damping of vibration at the first resonant mode for each combination of coefficient gains is different. From Table 1, it can be concluded that the highest active damping on the first resonant frequency is realized with the following factors, $K p=3.0, K i=0.04, K d=45$. The magnitude is decreased $95.08 \%$, which is a better result than in the case of the gains obtained by the Ziegler-Nichols method $92.64 \%$.

However, from table 1 and figure 7 , it can be concluded that the coefficients of the highest damping at the first mode are not the optimal coefficient gains, because the sensor output signal in the time domain is increased with regard to the output signal of other 
coefficients. With increasing of the coefficient gains, the time output signal from simple sinusiodally shape get complex shape. The time response for sensor output for different PID factors is shown in Figure 8.

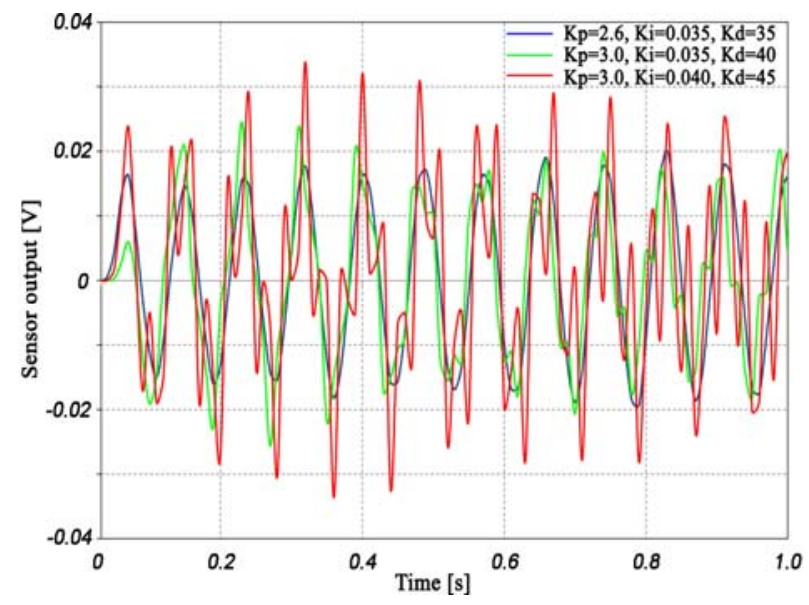

Figure 8. Time response for sensor output for different proportional-integral-derivative (PID) factors

From figure 8 it can be concluded that the increased in coefficient gains of PID controller has two effects. The first effect is decreasing in amplitude on first mode (bending), the controlled mode and second effect is in increasing the amplitude at higher mode (second modetwisting). The frequency response of sensor signal for different values of PID gains are presented in figure 9.
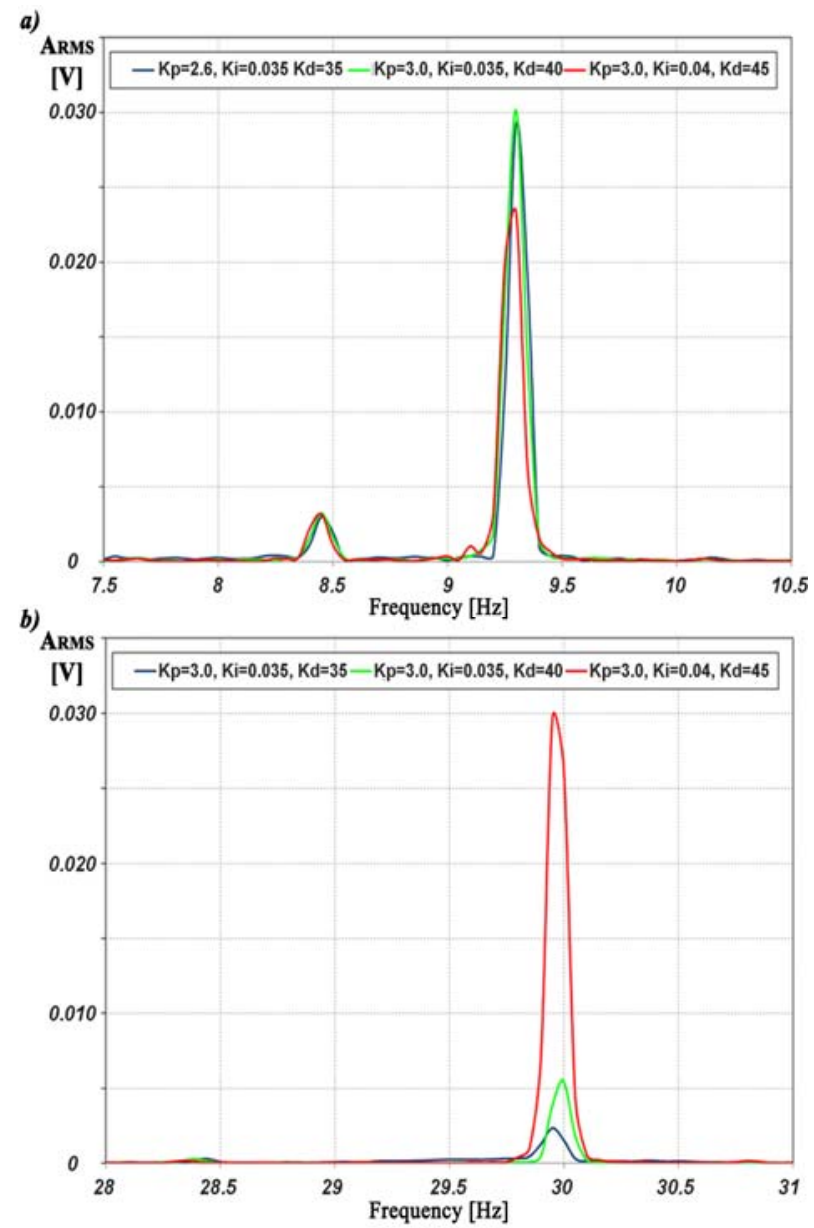

Figure 9. The frequency response of sensor signal using fast Fourier transform for different values of PID factors: (a) first resonant frequency; (b) second resonant frequency.
The coefficient gains are determined by the ZieglerNichols method need to be adjust. The best performances of active vibration control sistem for first mode will be realized when the output signal has minimal amplitude in sinusoidal shape. The best performances is obtained with following coefficient gains: $K_{p}=2.6, K_{i}=0.035, K_{d}=35$. The amplitude of output signal at first mode is $A_{\text {RMS }}=29.42 \mathrm{mV}$. The futher increasing of coefficient gains in active vibration control leads to deacreasing the amplitude at first mode, $\mathrm{A}_{\mathrm{RMS}}=23.85 \mathrm{mV}$ with $K_{p}=3.0, K_{i}=0.040, K_{d}=45$, but the second mode reached the value of $A_{R M S}=29.39$ $\mathrm{mV}$.

It is obviously that the active vibration system is infected with spillover effect according to feedback excites the unmodeled state. Active vibration control system is modelled for first bending mode of composite beam. With increasing the coefficient gains of PID controller, the stability margin of active vibration contol system will be perturbed at second mode. The spillover effect will not lead to full instability of system, but its appear in system will reduce the performances of active vibration control system. In practice, the appear of spillover effect will not remarked when the system is in working process, but in the case when the external disturbance is stoped the active structure will oscillate at the residual mode. The increasing in oscillate amplitude with change of differential gain and fixed proportionam and integral gains is shown in figure 10.

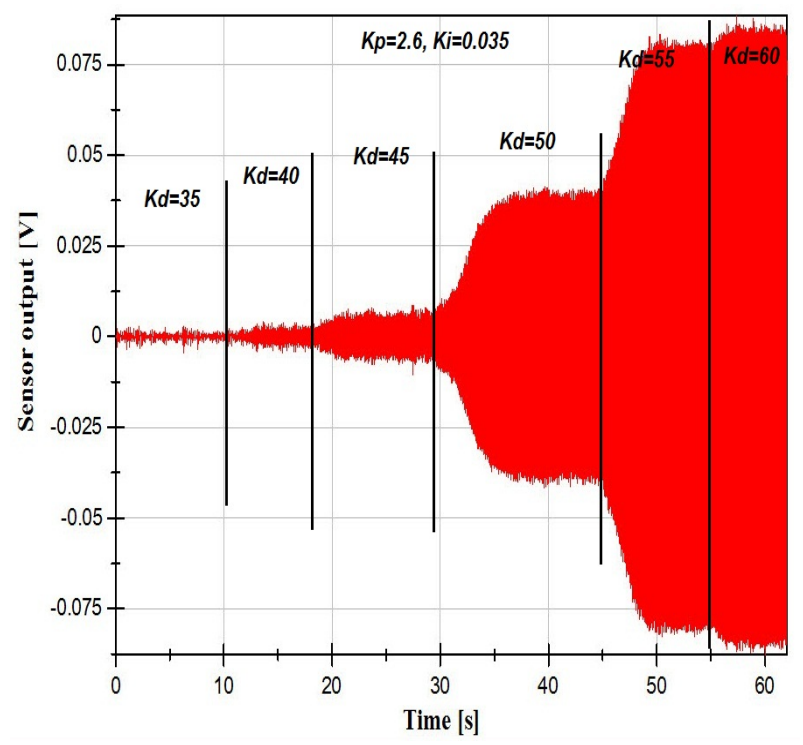

Figure 10. The sensor output (amplitude) in function of differential gain increasing

After all conducted experiments, the obviously fact is that the spillover effect can be affected with change of all three coefficients, but the differential gain has a major influence on spillover effect.

Methods for reduced spillover effect are different and approach to decrease its influence is different too. Good solution is a combination of optimal approach to the reduction of control spillover associated with the active vibration control of a distributed structure, but this method requires the improvement of whole active vibration system. The second solution is the change of 
sensor position in order to decrease the signal contamination (observation spillover). This method requires the change of sensor platform position in active structure.

\section{CONCLUSION}

This paper describes a experimental investigation of spillover effect influence on developed active vibration control system.

The proportional-integral-differential controller (PID) is seen to add high damping to the first mode of the active structure. The optimal damping of system is reached with coefficient gains of PID controller, $K_{p}=2.6, K_{i}=0.035, K_{d}=35$.

The feedback excites the residual mode (second mode) of composite active structure. These appear is named as control spillover. The developed system does not consider the influence of residual modes, which lead in system performance decrease, but will not lead to full instability of system.

The conducted investigation is evidenced that all three coefficient gains of PID controller can induce spillover effect. The control spillover effect can be prevented by development a higher order controller. As a result, it reduces the resonant response of these modes, and reduces the effects of control spillover.

Future research will conduct the improvement the controller of active vibration control system with aim to control the larger number of modes.

\section{ACKNOWLEDGMENT}

This work is supported by the Ministry of Science and Technological Development of Republic of Serbia through Technological Development Projects No. 35035 .

\section{REFERENCES}

[1] Worden K, Bullough W A and Haywood J 2003 Smart Technologies (Singapore: World Scientific)

[2] Dong X., Peng Z., Zhang W., Hua H.X., and Meng G.: Research on Spillover Effects for Vibration Control of Piezoelectric Smart Structures by ANSYS, Math. Probl. Eng., Vol. 2014, 8 pages, 2014.

[3] Kumar K.R. and Narayanan S.: The optimal location of piezoelectric actuators and sensors for vibration control of plates, Smart Mater. Struct., Vol. 16, pp. 2680-2691, 2007.

[4] Wang S.Y., Quek S.T. and Ang K.K.: Vibration control of smart piezoelectric composite plates Smart Mater. Struct., Vol. 10, pp. 637-644, 2001.

[5] Yang Y., Jin Z. and Soh K.C.: Integrated optimal design of vibration control system for smart beams using genetic algorithm, J. Sound Vib., Vol. 282, pp.1293-1307, 2005.

[6] Jovanović M.M., Simonović M.A., Zorić D.N., Lukić S.N., Stupar N.S. and Ilić S.S.: Experimental studies on active vibration control of a smart composite beam using a PID controller, Smart Mater. Struct., Vol. 22, 115038 (8pp), 2013.

[7] Khot S.M., Yelve N.P., Tomar R., Desai S. and Vittal S.: Active vibration control of cantilever beam by using PID based output feedback controller, J. Vib. Control, Vol. 18, pp. 366-372, 2011

[8] Alkhatib R. and Golnaraghi F.M.: Active Structural Vibration Control: A Review, The Shock and Vibration Digest, Vol. 35, No. 5, pp.367-383, 2003.

[9] Mei C. and Mace B.R.: Reduction of Control Spillover in Active Vibration Control of Distributed Structures Using Multioptimal Schemes, J. Sound Vib., Vol. 251, No. 1, pp. 184-192, 2002.

[10] Kim M.H. and Inman D.J.: Spillover Reduction in the Vibration Control of Flexible Structures Using Sliding Mode Observer, J. Vib. Control, Vol. 7, pp. 1087-1105, 2001.

[11] Simonović M.A., Jovanović M.M., Lukić S.N., Zorić D.N., Stupar N.S. and Ilić S.S.: Experimental studies on active vibration control of smart plate using a modified PID controller with optimal orientation of piezoelectric actuator, J. Vib. Control, doi: 10.1177/1077546314549037, 2014

[12] Gosiewski Z.,. Koszewnik P.A.: Fast prototyping method for the active vibration damping system of mechanical structures, Mech. Syst. Signal Pr., Vol. 36, pp. 136-151, 2013.

[13] Iwamoto H., Tanaka N. and Hill S. G.: Feedback control of wave propagation in a rectangular panel, part 2: Experimental realization using clustered velocity and displacement feedback, Mech. Syst. Signal Process, Vol. 32, pp. 216-231, 2012

\section{ЕКСПЕРИМЕНТАЛНО ИСТРАЖИВАЊЕ „SPILLOVER“ ЕФЕКТА У СИСТЕМИМА АКТИВНОГ УПРАВЉАЫА ВИБРАЦИЈАМА}

\section{Мирослав М. Јовановић, Александар М. Симоновић, Немања Д. Зорић, Небојша С. Луић, Слободан Н. Ступар, Ана С. Петровић, Wei Li}

Пиезоелектрични актуатори се увелико примењују за активно управљање вибрацијама на разним структурама са циљем повећања перформанси система. Развијени систем активног управљања вибрацијама се састоји од активние структуре, контролера и високонапонских појачивача. У овом раду, композитна греда представља основну структуру за сензорску (мерне траке) и актуаторску (двослојни PZT пиезоелектрични актуатор) платформу. $\mathrm{Y}$ циљу унапређења динамичких карактеристика активног система вршена је промена коефицијената ПИД регулатора. Ефикасност система активног управљања вибрацијама за посматрани мод осциловања се може повећати променом коефицијената ПИД регулатора, али у исто време могуће је нарушити стабилност система. 
Нестабилност система је најчешће условљена појавом „spillover“ ефекта. У овом раду представљен је значај „spillover“ ефекта у затвореним петљама пиезоелектричних активних структура, као и значај промене коефицијената ПИД регулатора на стабилност система. Експериментални резултати система активног пригушења вибрација су представљени у раду и дају једну од могућности за повећање стабилности управљаних структура. 